\title{
Protein FosB
}

National Cancer Institute

\section{Source}

National Cancer Institute. Protein FosB. NCI Thesaurus. Code C26606.

Protein fosB (338 aa, $\sim 36 \mathrm{kDa}$ ) is encoded by the human FOSB gene. This protein plays a role in transcriptional regulation. 